DOI: https://doi.org/10.34069/AI/2022.49.01.20

How to Cite:

Vershinin, V.P., Zheltukhina, M.R., Slyshkin, G.G., Anikeeva, I.G., \& Sausheva, Y.V. (2022). Modern means of communication in professional education. Amazonia Investiga, 11(49), 182-188. https://doi.org/10.34069/AI/2022.49.01.20

\title{
Modern means of communication in professional education
}

\section{СОВРЕМЕННЫЕ СРЕДСТВА КОММУНИКАЦИИ В ПРОФЕССИОНАЛЬНОМ ОБРАЗОВАНИИ}

Received: November 1, 2021

Abstract

The purpose of the article is analysis of communication tools implementation in vocational education. In the course of scientific research, relevant means of communication were identified. The analysis of students' thesaurus development shows effectiveness of chosen educational tools and means in the process of professional training. Modern means of communication expand possibilities of professional training of students. Students must be ready to perform team activities, learning to conduct a professional dialogue in order to achieve the set goals.

Key Words: means of communication, social communication, communication, practiceoriented educational environment, thesaurus, electronic means of communication.

\section{Introduction}

The new era of global information and the desire for adaptation in the context of digital globalization have led to the emergence of means that change the type of interaction of individuals in society. Globalization is entering the next
Accepted: January 4, 2022

Written by:

Valentin P. Vershinin ${ }^{78}$

https://orcid.org/0000-0002-5882-1392

Marina R. Zheltukhina ${ }^{79}$

https://orcid.org/0000-0001-7680-4003

Gennady G. Slyshkin ${ }^{80}$

https://orcid.org/0000-0001-8121-0250

Irina G. Anikeeva ${ }^{81}$

https://orcid.org/0000-0001-9628-4287

Yelena V. Sausheva ${ }^{82}$

https://orcid.org/0000-0002-7744-9071

\begin{abstract}
Аннотация
Целью статьи является анализ реализации средств коммуникации в профессиональном образовании. В ходе научного исследования были выявлены актуальные средства коммуникации, используемые в отечественных и зарубежных учебных заведениях. Анализ сформированности тезауруса студентов показывает результативность используемых в процессе профессиональной подготовки средств. Современные средства коммуникации расширяют возможности профессиональной подготовки студентов. Готовые к осуществлению совместной деятельности, обучающиеся способны вести профессиональный диалог с целью достижения поставленных целей.
\end{abstract}

Ключевые слова: средства коммуникации, социальная коммуникация, общение, практикоориентированная образовательная среда, тезаурус, электронные средства коммуникации.

digital phase, where the role of information flows and data exchange channels is increasing. Thus, there is a need for introduction and use of modern communication tools in vocational education. Since students are the most active stratum of

\footnotetext{
${ }^{78}$ Moscow Psychological and Social University, Russian State University for the Humanities, Moscow, Russia

${ }^{79}$ Volgograd State Socio-Pedagogical University, Volgograd, Russia.

${ }^{80}$ Russian University of Transport (MIIT), Moscow, Russia.

${ }^{81}$ Moscow Aviation Institute, Moscow, Russia.

${ }^{82}$ Military University of the Ministry of Defense of the Russian Federation, Moscow, Russia.
} 


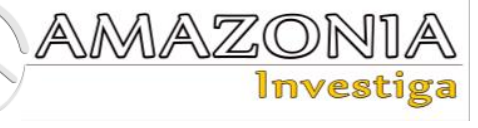

society, showing a high readiness to use innovative tools and striving for dynamic selfdevelopment, the involvement of modern means of communication in educational process is the most valuable and relevant (Vaganova et al., 2020a).

Modern education today can be represented as a complex communication system, in which both level and quality of the submitted material are important, as well as the transmission channels used in this process, ensuring the required speed of receiving messages that provide feedback. Exactly these factors often affect self-realization of students in research activities, various projects, competitions, contests and other events aimed at developing professional competence and soft skills of students (Vaganova et al., 2020b).

The task of a modern university is to involve students in the active use of communication tools to organize professional interaction (Nezhelskaya, 2020). In the process of professional training, students know new models and types of social communication.

Since emotional and psychological aspects of communication are important in the preparation process, it is necessary to pay attention to these components as necessary elements of network communication in teaching a competent specialist (Kiseleva et al., 2019; Shmeleva et al., 2020). These processes are closely related to creation effective practice-oriented educational process (Petrovicheva E.A. at al., 2019).

The more active the communication process is, the faster the feedback and the higher the possibility of achieving higher educational results are.

The level of professional communication reflects terminological and conceptual apparatus development, developed with the help of modern electronic means. Considering the conceptual apparatus, we speak of it as one of the indicators of the ability to carry out professional interaction and readiness to carry out professional activities.

The relevance of communication means will reveal the analysis of electronic tools used for interaction both in Russia and abroad.

\section{Theoretical framework}

Communication is a dialogue with the aim of transmitting a certain amount of information. The concept of social communication became widespread precisely with the beginning of the development of information and communication technologies, when communication began to include emotional aspect (which appeared primarily in full-time training) (Akvazba et al., 2019; Goncharov et al., 2021). In the conditions of electronic interaction, communication involves not only informational, but also personal-existential communication (which originally referred only to the concept of "communication") (Mazanyuk et al., 2020). In other words, it is necessary to pay attention to the fact that universities are solving the problem of building social communication between students, including the transfer of information and active interpersonal emotionally colored communication, contributing to the solution of professional problems and issues in an online format (Aleshchanova et al., 2018; Nagovitsyn et al., 2020).

Communication as a directed connection is a universal mechanism for transforming sociocultural space, forming a professional thesaurus of students (Kharytonov et al., 2019), training a competent specialist capable of interacting within a team (Dobudko et al., 2019).

Modern means of communication make it possible to realize its integral functions: activation, prohibitive, destabilizing (Vaganova et al., 2020a). The activation function allows you to activate the student's performance, to induce him to perform certain actions (Demidov et al., 2020). The prohibitive function prohibits the learner from all but one action to assess possible risks (Ivanova \& Korostelev, 2019). The task of destabilizing function is to show the complexity and multidimensionality of professional tasks and life in general (Bulaeva, et al., 2018). If a student adheres to one opinion and accepts one of the sides, then he is forced to oppose it to other opinions. In digital environment, these processes cause certain difficulties (Tsarapkina et al., 2021 ; Zheltukhina et al., 2021). Revealing some aspects of communication process, we pay attention to the features of the "implementation of the capabilities of modern means of its construction (Pinkovetskaia et al., 2020)

Modern means of communication make it possible to build a high-quality training process in a remote format by structuring educational space, taking into account the emotional component of the personality of students and selecting the appropriate educational technologies that develop necessary competencies (Mazanyuk et al., 2020). At the same time, we pay attention to such means of 
communication that contribute to development, first of all, of professional competencies) (Efremenko et al., 2020).

Electronic means of communication are usually called tools that facilitate the organization of the process of transferring information and necessary materials to each other. Various applications and educational platforms are involved, which means communication through text messages, file transfer, and through webinars, conference calls, video calls (Shashlo et al., 2018).

Issues of communication interaction are also explored in the following publications (Golovanov et al., 2021); (Demidov et al., 2016a); (Demidov et al. 2019); (Moskvina et al., 2019); (Demidov et al., 2016b).

\section{Methodology}

The study involved 354 students of higher educational institutions. The article presents an analysis of scientific works, which made it possible to identify the percentage of communication tools used by students for educational purposes in domestic and foreign educational institutions. Communication tools were divided into two categories: messengers for the operational interaction of students performing a project (any other task) in one team and communication tools that offer the widest functionality, allowing you to exchange not only messages, but also large enough files, while interacting not only with my fellow students, but also with teachers.
To check development of professional thesaurus, a scale from 1 to 5 points was used, where 5 is $100 \%$. Each point is assigned a qualitative characteristic of a specific indicator. The use of pedagogical testing made it possible to identify the student's average score for a specific communicative quality of a professional thesaurus. The average score was distributed by levels: less than 2 points - low level, 2-2.6 below average, 2.7-3.4 - average level, 3.5-4.3 above average, 4.4-5 - high level. Using the method of qualitative characteristics, an assessment was made of the formation of a professional thesaurus and its communicative qualities.

\section{Results and discussion}

Organization of internal and external communications occurs using variety of means. An electronic survey among students made it possible to identify a variety of means of communication and communication used in learning process. The tools were divided into two categories. The first category: for individual use in the process of performing practical work (for operational interaction between students who are in the same team or subgroup). The second category: for mass use (at the university level and for performing larger-scale work in an electronic environment).

The table presents the results of the means of communication analysis used by foreign and domestic students.

Table 1.

Domestic and foreign means of communication in the electronic space.

\begin{tabular}{llllll}
\hline 1 & $\%$ & & 2 & $\%$ & \\
\hline $\begin{array}{l}\text { First } \\
\text { category }\end{array}$ & $\begin{array}{l}\text { Domestic } \\
\text { educational } \\
\text { institutions }\end{array}$ & $\begin{array}{l}\text { Foreign } \\
\text { educational } \\
\text { institutions }\end{array}$ & $\begin{array}{l}\text { Second } \\
\text { category }\end{array}$ & $\begin{array}{l}\text { Domestic } \\
\text { educational } \\
\text { institutions }\end{array}$ & $\begin{array}{l}\text { Foreign } \\
\text { educational } \\
\text { institutions }\end{array}$ \\
WhatsApp & $80 \%$ & $18 \%$ & LMS & $78 \%$ & $30 \%$ \\
Viber & $82 \%$ & $15 \%$ & MOODLE & $77 \%$ & $80 \%$ \\
Telegram & $90 \%$ & $60 \%$ & Coursera & $2 \%$ \\
Discord & $40 \%$ & $70 \%$ & Geekbrains & $35 \%$ & $30 \%$ \\
VK & $78 \%$ & $5 \%$ & Mirapolis & $45 \%$ & $32 \%$ \\
Facebook & $40 \%$ & $80 \%$ & iSpring Learn & $40 \%$ & $26 \%$ \\
WeChat & $15 \%$ & $85 \%$ & Web Tutor & $43 \%$ & $46 \%$ \\
QQ & $5 \%$ & $69 \%$ & Canvas & $47 \%$ & $75 \%$ \\
Snapchat & $23 \%$ & Google & $70 \%$ & \\
Line & $4 \%$ & $43 \%$ & Classroom & & \\
Zoom & $86 \%$ & $25 \%$ & & & \\
\multicolumn{1}{c}{ Skype } & & $50 \%$ & $69 \%$ & & \\
\hline
\end{tabular}




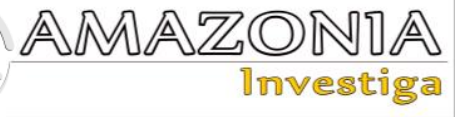

The number of people using WhatsApp and Viber abroad is mainly Russian-speaking. In overseas educational institutions, students prefer to use Facebook, WeChat and Discord. Russian students most often use WhatsApp, Viber, Telegram, as well as the VK social network. Frequently used electronic educational platforms in Russia include Moodle, Coursera (despite the

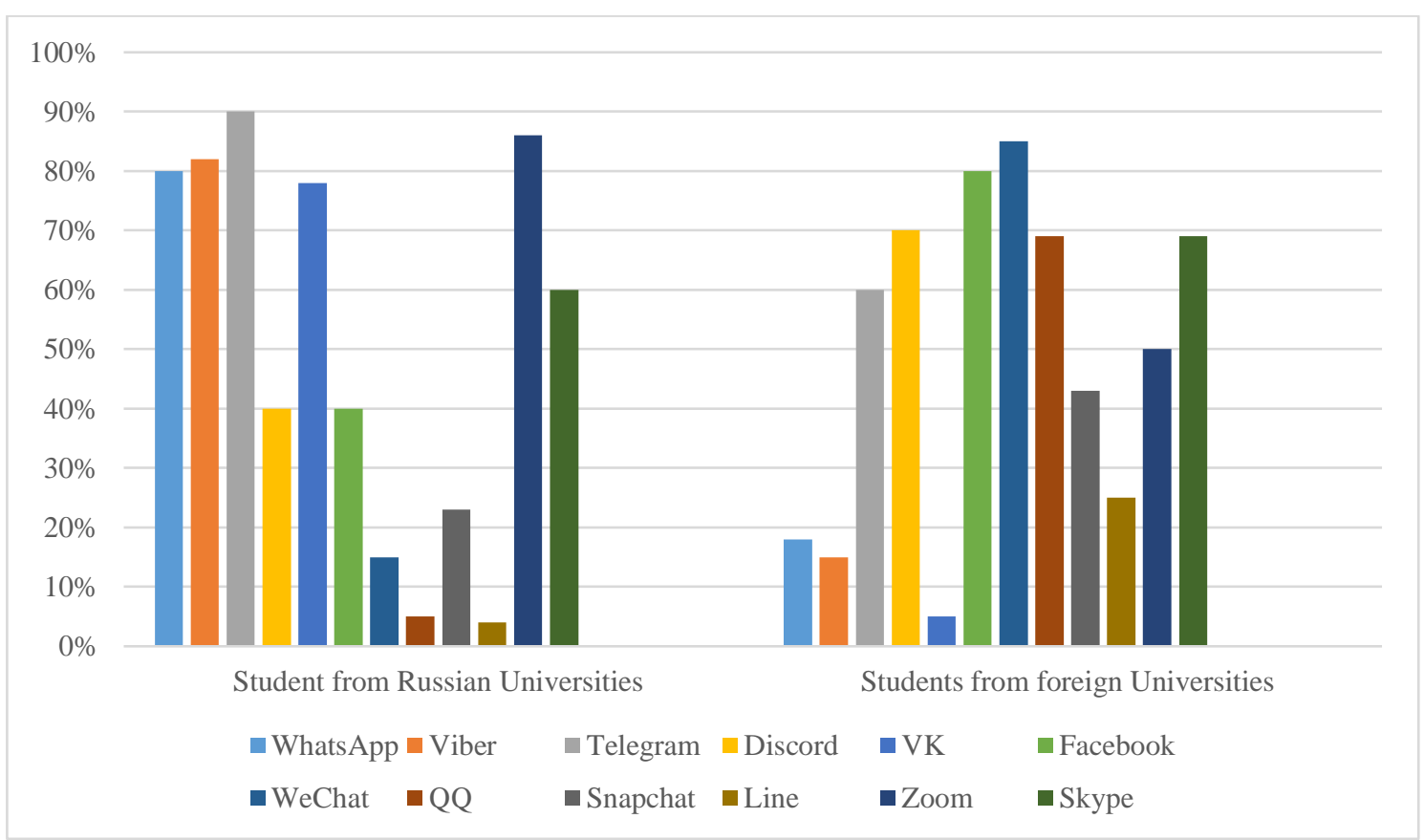

Fig. 1. Graphical results of research data in the first category (based on the analysis of scientific literature)

(Moscow Psychological and Social University, Russian State University for the Humanities, Volgograd State Socio-Pedagogical University, Russian University of Transport (MIIT), Moscow Aviation Institute, Military University of the Ministry of Defense of the Russian Federation) fact that this platform is massive open online courses), as well as Google Classroom. Overseas, Coursera and Google Classroom are of the greatest interest. As a means of conducting webinars, students most often choose Zoom and Skype.

Further, the data is presented in graphical form. 


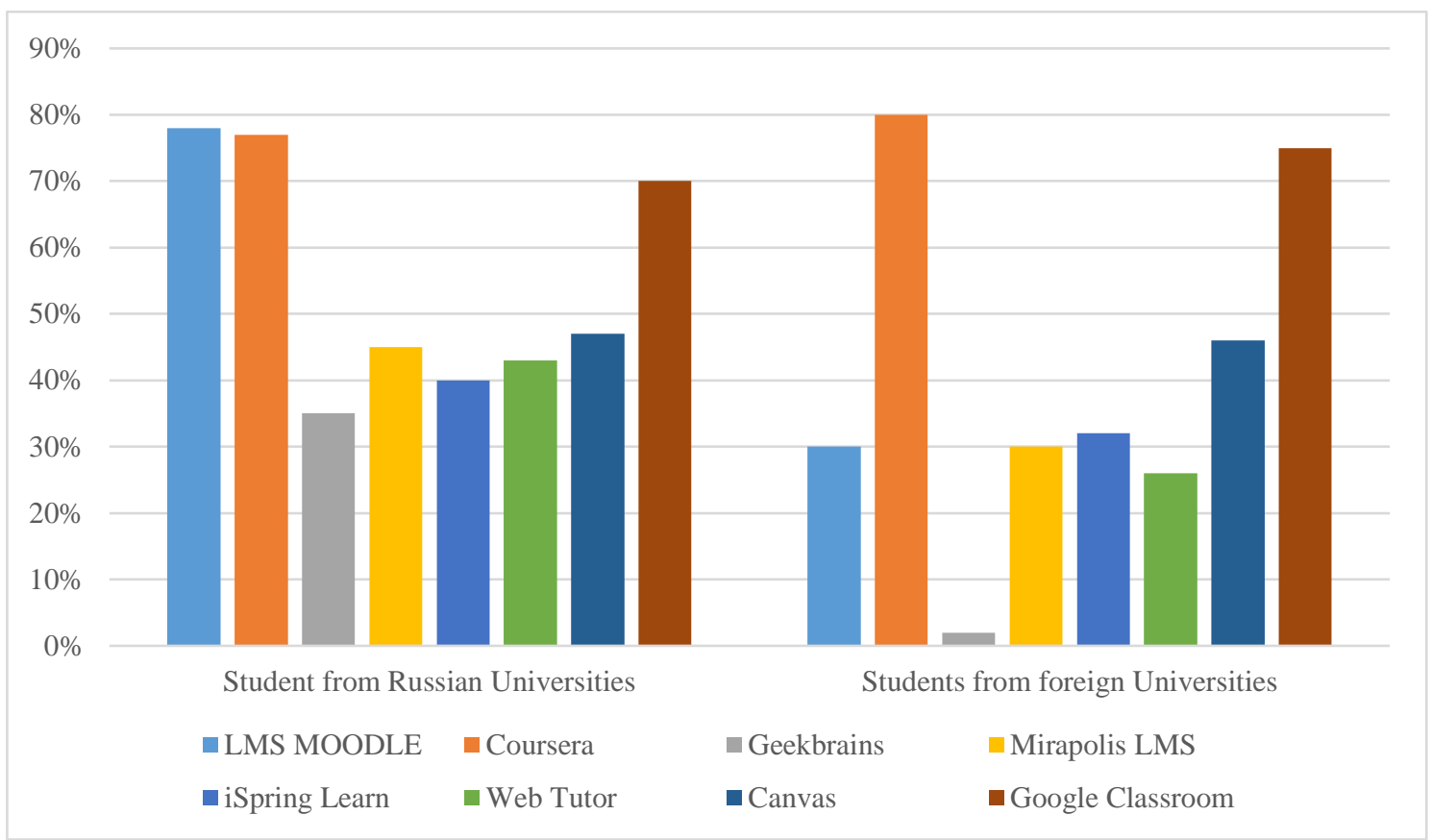

Fig. 2. Graphical results of research data in the second category (based on the analysis of scientific literature)

Each student has the right to choose the most convenient means of communication. Modern conditions for the development of technical means make it possible to do this. Moreover, universities themselves aim students at independent selection of necessary tools, which will be used not only for educational, but also for professional purposes. Technological advances change the tools used. The more a student masters them, the easier it is for him to adapt to new types in future professional activities.

The verification of professional thesaurus development was carried out in the process of studying the discipline "Pedagogical technologies". The preparation of future teachers of vocational training is accompanied by a large number of specific terms that must be used in professional practice. This reflects readiness of a specialist to carry out professional activities at a high level. Input control showed that conceptual apparatus of students includes an average of 27 words. In the learning process, where students were engaged in the implementation of projects, various scientific works, took part in scientific conferences and professional competitions, the mastery of professional terms and concepts reached 150 words.

The study showed that the most formed quality of a professional thesaurus of all are those ones that are offered to students (compliance with spelling and grammatical norms, correct use of terminology, accuracy, consistency) with the correctness of terminology use (score above average).

\section{Conclusions}

Modern means of communication provide many opportunities for organizing a practice-oriented educational process, which includes emotional components that are significant for development of a competent specialist in the process of information exchange.

The conducted research allows us to speak about the effectiveness of communication means used in students' training.

Paying attention to the thesaurus formed by students, it should be said that students acquire a large amount of information on their own, organically, in the process of interaction, directing each other through the operatively used means of communication. The conceptual apparatus of a student expands significantly after active interaction. With the controlling role of the teacher, the student masters not only basic concepts, but also terms broadening his scope.

In the course of the study, an increase in the level of formation of the conceptual apparatus was revealed. Students are ready for professional communication and ready for further professional self-improvement. 


\section{AMAZOND㐿 \\ 1กvestiீgீa}

Acknowledgments: The work has been supported by the RSF (project No. 22-2801623).

\section{Bibliographic references}

Akvazba, E., Bogdanova, V., Uzlova, N., \& Patrusheva, I. (2019). Problems and prospects of the Russian information society. Amazonia Investiga, 8(20), 310-322. Retrieved from https://amazoniainvestiga.info/index.php/am azonia/article/view/144.

Aleshchanova, I.V., Frolova, N.A., Zheltukhina, M.R. (2018). Evolution of Motives in Professional Personality Formation: Foreign Language Learning Context. In: Proceedings of the International Conference on the Theory and Practice of Personality Formation in Modern Society (ICTPPFMS 2018), Vol. 198, pp. 35-40. https://doi.org/10.2991/ictppfms18.2018 .8

Bulaeva, M. N., Vaganova, O. I., Koldina, M. I., Lapshova, A. V., \& Khizhnyi, A.V. (2018). Preparation of Bachelors of Professional Training Using MOODLE. Advances in intelligent systems and computing, 622, pp. 406-411.

Demidov, A.A., \& Tretyakov, A.L. (2016a). A network model of centers for ethical and legal education and civil-patriotic education and media education centers based on school libraries: the need to create, opportunities and real prospects. Media Education (Mediaobrazovanie), 3, pp. 16-22.

Demidov, A.A., \& Tretyakov, A.L. (2016b). Centers for ethical and legal information and media education based on the school library an innovation in the implementation of the Federal State Educational Standard and infrastructure for the development of information and legal culture of children and youth. Media Education (Mediaobrazovanie), 2, pp. 21-33.

Demidov, A., Syrina, T., \& Tretyakov, A. (2020). Development of Digital Skills and Media Education System: From the Organization of Environmental Education of Preschool Children to the ICT Competence of Teachers. Media Education (Mediaobrazovanie), 1, pp. 11-23. http://ejournal53.com/journals_n/158445660 8.pdf

Demidov, A., Melnikov, T., Moskvina, A., \& Tretyakov, A. (2019). The Organization of Ecological Education of Per-school Children by Means of Media Literacy Education: Theory, National Policy, Scientometrics and
Vectors of Development. Media Education (Mediaobrazovanie, 4, pp. 470-481. DOI: 10.13187/me.2019.4.470.

http://ejournal53.com/journals_n/158020096 3.pdf.

Dobudko, T.V., Korostelev, A.A., Gorbatov, S.V., Kurochkin, A.V., \& Akhmetov, L.G. (2019). The organization of the university educational process in terms of digitalization of education. Humanities and Social Sciences Reviews, 7(4), pp. $1148-1154$.

Goncharov, V.V., Zheltukhina, M.R, \& Anikeeva, I.G. (2021). The impact of global constitutionalism on the formation of social concepts in Russia. Laplage Em Revista, 7(Extra-A), pp. 330-342. https://doi.org/10.24115/S2446622020217Extra-A820p.330-342

Efremenko, L., Golovachev, V., Grigoryeva, A., Tretyakov, A., \& Chertakova, E. (2020). Environmental education technologies. Eduweb: Revista de Tecnología de Información y Comunicación en Educación, 2, pp. 109-122. http://servicio.bc.uc.edu.ve/educacion/eduwe b/v14n2/art08.pdf

Golovanov, V.P., Bykovskaya, T.E., Panteleeva, N.G., Fedorova, S.Yu., \& Tretyakov, A.L. (2021). Methodological strategy of modern preschool environmental education based on the resource approach. Prospects of science and education, 1, pp. 299-317. DOI: 10.32744/pse.2021.1.21. https://pnojournal.files.wordpress.com/2021/ 02/2101pno.pdf.

Ivanova, N., \& Korostelev, A. (2019). The impact of competitive approach on students' motivation in sport. Amazonia Investiga, 8(18), 483-490. Retrieved from https://amazoniainvestiga.info/index.php/am azonia/article/view/362

Kharytonov, E., Kharytonova, O., Tolmachevska, Y., Fasii, B., \& Tkalych, M. (2019). Information Security and Means of Its Legal Support. Amazonia Investiga, 8(19), 255-265. https://amazoniainvestiga.info/index.php/am azonia/article/view/227

Kiseleva, O., Lebedev, A., Pinkovetskaia, I., Rojas-Bahamón, M., \& Arbeláez Campillo, D. (2019). Specialization and concentration of small and medium enterprises employees: Russian data. Amazonia Investiga, 8(20), 6-15.

https://amazoniainvestiga.info/index.php/am azonia/article/view/59

Mazanyuk, E.F., Tretyakov, A.L., \& Amichba, L.R. (2020). Game technologies as 
a tool of motivation and improvement the quality of university students' training. SHS Web of Conferences: International Scientific and Practical Conference «Teacher Professionalism: Psychological and Pedagogical Support of a Successful Career» (ICTP 2020), Yalta, Russia, October 21-23, 2020. Vol. 87. 00108.

Moskvina, A.S., Bykovskaya, T.E., Panteleeva, N.G., Balabas, N.N., \& Tretyakov, A.L. (2019). Features of the implementation of the content of environmental education in a preschool educational organization. Perspectives of science and education, 5, pp. 271-288. DOI: 10.32744/pse.2019.5.20.

https://pnojournal.wordpress.com/archive19/ 19-05/.

Nagovitsyn, R. S., Vaganova, O. I., Kutepov, M. M., Kosenovich, O. V, Moeseev, Yu. V., Vorotova, M. S., \& Osipov, A. Y. (2020). Interactive Technologies in Developing Student's Motivation in Physical Education and Sport. International Journal of Applied Exercise Physiology, 9(6), 78-85.

Nezhelskaya, G. N. (2020). University educational environment (setting) as an object of students' social adaptation (integration). Scientific interdisciplinary research, (3-2), 154-159.

Petrovicheva, E.A., Galchenko, N.A., Tomin, V.V., Tretyakov, A.L., Lisitzina, T.B., Rozhnov, S.N., \& Vorobiev, S.V. (2019). Everyday life ecology: accessible environment for students with limited mobility. EurAsian Journal of BioSciences, 2, pp. 1559-1564.

Pinkovetskaia, I., Berezina, N., \& Sverdlikova, E. (2020). The main reasons for the exit of entrepreneurs from business. Amazonia Investiga, 9(26), 68-73. https://doi.org/10.34069/AI/2020.26.02.7

Shashlo, N., Petruk, G., \& Korostelev, A. (2018). Determinants of integration interaction among the subjects of the entrepreneurial innovation ecosystem of macro region. Amazonia Investiga, 7(13), 351-363. https://amazoniainvestiga.info/index.php/am azonia/article/view/569

Shmeleva, O.D., Zheltukhina, M.R., Slyshkin, G.G., Ryabko, G.P., Ostrikova, G.N., Ukhova, L.V., \& Gaponova, Z.Q. (2020). Media Influence: Cognitive and Psychological Markers (On Chinese Medical and Cosmetic Advertising Texts). Propósitos y Representaciones, Vol. 8, SPE(2), e798, http://dx.doi.org/10.20511/pyr2020.v8 nSPE2.798

Tsarapkina, J. M., Plahina, L. N., Konoplyuk, N. V., Vaganova, O. I., Lapshova, A. V. (2021). The formation of bachelors' digital competencies at the university. Propositos y representaciones, 9, № SI, Article number e811.

Vaganova, O. I., Bakharev, N.P., Kulagina, J. A., Lapshova, A.V., Kirillova, I. K. (2020a). Multimedia technologies in vocational education. Amazonia Investiga, 9 (26), 391-398. https://doi.org/10.34069/AI/2020.26.02.45

Vaganova, O. I., Petrozitskaya, I. A., Snatovich, A. B., Odarich, I. N., \& Kirillova, I. K. (2020b). Heuristic technologies of training in professional education. Heuristic technologies of training in professional education. Amazonia Investiga, 9(27), 509-517. DOI: 10.34069/AI/2020.27.03.55

Zheltukhina, M.R., Kutepov, M.M., Kutepova, L.I., Bulaeva, M.N., \& Lapshova, A.V. (2021). Development of students' media competence in the context of digital education. Eduweb Magazine, 15(1), 29-38. https://doi.org/10.46502/issn.18567576/2021.15.01.3 